\section{Evolokumab til alle med koronarsykdom?}

Et monoklonalt antistoff som reduserer LDL-kolesterolnivået kan sammen med statinbehandling gi mindre aterosklerose og plakk hos pasienter med koronarsykdom. Dette viser en ny studie.

Evolokumab er et monoklonalt antistoff som medfører redusert nedbrytning av LDLreseptorer på overflaten av hepatocytter og dermed også nivået av LDL-kolesterol. Medikamentet er i dag godkjent for bruk ved statinintoleranse samt ved homozygot familiær hyperkolesterolemi.

I en randomisert multisenterstudie fikk pasienter med koronarsykdom enten evolokumab eller placebo i injeksjon i 72 uker (1). Ved studiestart brukte nesten alle et statinpreparatat. De som fikk evolokumab, oppnådde signifikant lavere LDL-kolesterolnivå enn de som fikk placebo, henholdsvis $0,95 \mathrm{mmol} / \mathrm{l}$ og $2,41 \mathrm{mmol} / \mathrm{l}(\mathrm{p}<0,001)$, og en reduksjon i ateromvolum (målt ved intravaskulær ultralydundersøkelse) på $0,95 \%$, mot en økning på $0,05 \%$ hos dem som fikk placebo $(\mathrm{p}<0,001)$. Andelen som fikk regresjon av plakk var rundt $64 \%$ i evolokumabgruppen og rundt $47 \%$ i placebogruppen.

- Det er ikke overraskende at koronar plakkstørrelse progredierer i mindre grad ved bruk av evolokumab, sier Lars Gullestad, som er professor og overlege i kardiologi ved Oslo universitetssykehus. - Mer oppsiktsvekkende er det at en så stor andel oppnådde regresjon av aterosklerose. Det er også verdt å merke seg at det ikke ble funnet noen nedre grense for utgangsnivå av LDL-kolesterol for å oppnå effekt av evolokumab. Dette utfordrer dagens syn på behandlingsmålet for kolesterolsenkende behandling. Kanskje skal alle koronarsyke behandles, uansett nivå av total- eller LDLkolesterol, sier Gullestad, som tror at klinisk praksis først vil kunne endres etter at det er kommet resultater fra flere utfallsstudier.

\section{Petter Morten Pettersen}

Sykehuset Østfold

\section{Litteratur}

1. Nicholls SJ, Puri R, Anderson T et al. Effect of Evolocumab on Progression of Coronary Disease in Statin-Treated Patients: The GLAGOV Randomized Clinical Trial. JAMA 2016. E-publisert 15.11.2016.

\title{
Høy dødelighet ved diabetes i Mexico
}

\author{
Diabetes er vanlig i Mexico, blodsukkerkontrollen er dårlig og prognosen \\ mye dårligere enn i høyinntekstland.
}

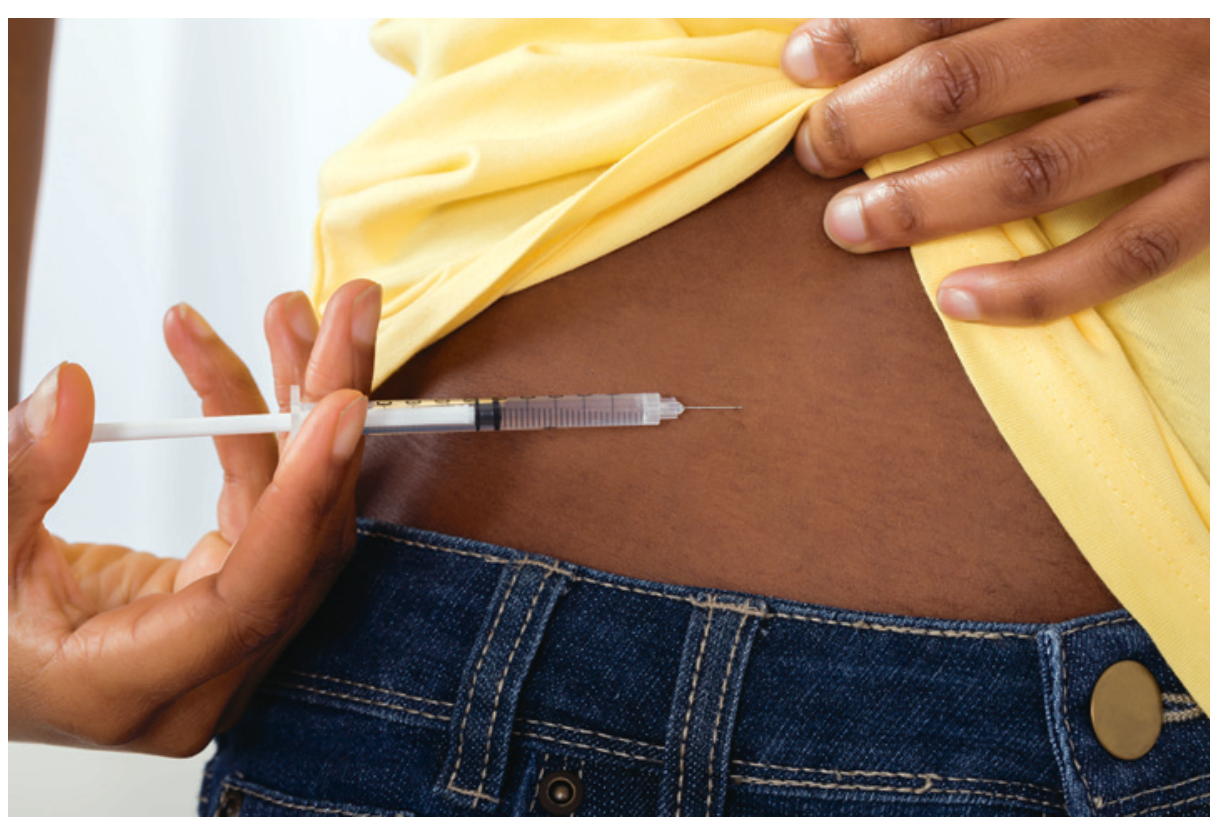

Illustrasjonsfoto: Thinkstock

Mexico er et av landene i verden med høyest forekomst av fedme og type 2-diabetes. I en prospektiv studie med rundt 150000 voksne i alderen 35-84 år ble personer med andre kroniske sykdommer enn diabetes ekskludert (1). Ved studiestart var prevalensen av diabetes $3 \%$ i aldersgruppen 35-39 år og opptil $20 \%$ hos deltagere i 60 -årsalderen. Til tross for at så mange som rundt $80 \%$ av dem med kjent diabetes fikk medikamentell behandling for å kontrollere blodsukkernivået, var gjennomsnittlig nivå av glykosylert hemoglobin $\left(\mathrm{HbA}_{1 \mathrm{c}}\right)$ 9,0\% ved studiestart.

Etter om lag 12 års oppfølging var den relative risikoen for $\mathrm{d} \varnothing \mathrm{d} 5,4(95 \% \mathrm{KI} 5,0-6,0)$ for dem med diabetes i aldersgruppen 35-59 år, sammenlignet med dem som ikke hadde diabetes ved studiestart. I aldersgruppene 60-74 år og 75-84 år var den relative risikoen for død henholdsvis 3,1 (95\% KI 2,9-3,3) og $1,9(95 \% \mathrm{KI} 1,8-2,1)$. Sammenhengen mel- lom diabetes og $\mathrm{d} ø \mathrm{~d}$ var sterkest for $\mathrm{d} ø \mathrm{~d}$ som følge av nyresykdom, med en relativ risiko på $31,1 \quad(95 \%$ KI 24,3-39,8) i aldersgruppen 35-59 år. Akutt diabetisk krise lå bak $8 \%$ av dødsfallene hos dem med diabetes. Risikoen for død av hjerte- og karsykdom, infeksjoner og magesår var også økt. Diabetes var derimot ikke assosiert med høyere dødelighet av kols eller kreft.

Forfatterne konkluderer med at diabetes er vanlig i Mexico, at blodsukkerkontrollen er dårlig, og at prognosen er mye dårligere enn i høyinntektsland.

\section{Matilde Risopatron Berg}

Sykehuset Innlandet, Hamar

\section{Litteratur}

1. Alegre-Díaz J, Herrington W, López-Cervantes M et al. Diabetes and cause-spesific mortality in Mexico City. N Engl J Med 2016; 375: 1961-71. 